\title{
Impact of Micro-Credit on Economic Empowerment of Women in Madurai, Tamilnadu: A Study
}

\section{Selvaraj $\mathbf{N}^{*}$}

Department of Commerce, Saraswathi Narayanan College, Tamilnadu, India

\begin{abstract}
Economic empowerment of women is mainly based on their participation in decision making process with regard to raising and distribution of income, investments and expenditure at all levels. The entire efforts of empowering women are to help them to exercise their rights in decision making at all levels both within and outside the households and enable them to be treated as equal partners in the society. Efforts are on to enhance the capacity of women to earn and ensure that they get access to and control the whole family or community assets. Various institutions are involved in the delivery of microfinance services, especially since the dawn of the 1980s. They include formal commercial banks, rural banks, and NGOs. Women are the major beneficiaries of MFI/Ps, and the destination of the funds mainly includes agriculture, trading, small craft, processing units and consumption. The administrative structure is, in general, simple and the entire process is participatory in nature. Women play a predominant role in our economy and there is always a dire need to bring them into the mainstream of economic activities by breaking out the shackles of old, traditional customs where women are by and large confined to household activities.
\end{abstract}

Keywords: Empowerment; Micro-credit; Parameters and Indices

\section{Introduction}

Empowerment of women both economically and socially is imperative which has come to be accepted and considered desirable. Social, economic and decision making empowerment of women would include taking control over their lives, becoming conscious of their own situation and gaining skills, building self-confidence, solving problems and developing self-reliance.

Economic empowerment of women is mainly based on their participation in decision making process with regard to raising and distribution of income, investments and expenditure at all levels. The entire efforts of empowering women are to help them to exercise their rights in decision making at all levels both within and outside the households and enable them to be treated as equal partners in the society. Efforts are on to enhance the capacity of women to earn and ensure that they get access to and control the whole family or community assets.

The present paper is an attempt to examine the impact of micro credit on economic empowerment of respondents in the study area of various sectors such as manufacturing, service and trading sectors.

\section{Traditional models of micro lending}

Informal and small-scale lending arrangements have long been in existence in many parts of the world, especially in rural areas. They provide the rural population access to loans within their localities and cushion against the vagaries of economic fluctuations; they also foster a cooperative and community feeling among the rural people. The groups formed among the local people provide joint guarantee to repayment of loans and serve as instruments for spreading information useful for their economic and social progress.

They work among people who have some common characteristics and use their members' own resources for financing the loans. But in most cases, these institutions fail to reach the poor adequately. Hence, the emergence of a set of new institutions in recent years for catering to the needs of the poor.

\section{Emergence of microfinance}

Various institutions are involved in the delivery of microfinance services, especially since the dawn of the 1980s. They include formal commercial banks, rural banks, and NGOs. Their methods of doing business range from the Grameen Bank-style of solidarity groups and institutions dealing with individual clients to self-managed selfhelp groups. These institutions provide relatively small loans and their repayment periods are relatively short. Women are the major beneficiaries of MFI/Ps, and the destination of the funds mainly includes agriculture, trading, small craft, processing units and consumption. The administrative structure is, in general, simple and the entire process is participatory in nature.

The interest rates charged by micro lending schemes are kept high with a view to covering all the costs. Nonetheless, the rates of repayment to loans is claimed to be quite high, an achievement attributable mainly to the informal participatory structures of the system which create an atmosphere in which debtors honour their obligations. The prominence given to microcredit in recent times owes much to the success of a few microcredit programmes/institutions and the saga of their remarkable growth.

Women play a predominant role in our economy and there is always a dire need to bring them into the mainstream of economic activities by breaking out the shackles of old, traditional customs where women are by and large confined to household activities.

As per the ILO report of 1997, about $10 \%$ of the world's income are received by women, though they represent $50 \%$ of the world's population and perform two third of the total work in the world. "Women make up nearly 70 percent of the world's poor and 65

*Corresponding author: Selvaraj N, Department of Commerce, Saraswathi Narayanan College, Tamilnadu, India, Tel: 9843727975; E-mail: selvaraj_narayanan@yahoo.com

Received September 06, 2016; Accepted November 08, 2016; Published November 15, 2016

Citation: Selvaraj N (2016) Impact of Micro-Credit on Economic Empowerment of Women in Madurai, Tamilnadu: A Study. J Glob Econ 4: 227. doi: 10.4172/23754389.1000227

Copyright: ( 2016 Selvaraj N. This is an open-access article distributed under the terms of the Creative Commons Attribution License, which permits unrestricted use, distribution, and reproduction in any medium, provided the original author and source are credited. 
percent of the world's illiterate. Women work longer hours and are paid an average 25 percent less than men, but have made significant gains in entering formally male dominated jobs in the global labour force" India is far behind in this respect and women constitute $60 \%$ of the rural unemployed and $56 \%$ of the total unemployed. The Human Development Report points out that out of 1.3 billion poor people 70 percent are women.

Kulshrestha [1] has identified lack of capital as a serious constraint to development for women in rural areas. She identified the following difficulties that women face in applying for credit:

- Certification of identify.

- Lack of assets for furnishing security.

- The co-signing of loan by the husband since the women's rights to property is often restricted.

- Co-operating does not accept the women as a member if a male member of the family is already registered.

- The necessity for traveling long distances frequently to transact the loan.

- The majority of rural women are illiterate.

These constraints push the women to informal sources of finance. Though, borrowing from friends, relatives, moneylenders and pawnbrokers has several advantages, like easy access, immediacy of loan disbursement, micro-loan sizes, minimum collateral, etc., the disadvantages outweigh these advantages. The high interest rates prove to be very costly to the women and they become dragged in the vicious nets of money lenders.

Therefore, there must be a system that can provide solutions to credit problems of women. It is in this context that micro-finance assumed great importance.

\section{Objectives of the Study}

To evaluate the impact of micro-credit on women empowerment with reference to economic and to offer suitable suggestions based on the findings.

\section{Period of Study}

The present study is based on the primary. The primary data have been collected from the respondents directly for the period of study is impounded to one year. (i.e., 2015-2016).

\section{The Analytical Framework}

In order to measure the economic impacts on beneficiaries of micro credit, the Economic and Social Empowerment (ESE) index was computed for each member combining the social and economic parameters using the scoring technique applied by Singh, Padam and Rattan Chand.

The index of economic indicators (En) is given by

$$
\frac{\sum E_{j}}{\sum E_{j}(\max )}
$$

$E_{i}$ represent $j^{\text {th }}$ economic indicator.

$E_{j(\max )}$ are the maximum scores of $j^{\text {th }}$ economic indicator can take.

In order to examine the relationship between the level of empowerment and economic factors, the chi - square test has been applied. It is calculated by adopting the following formula.

$$
\begin{aligned}
& \text { Chi-square }=\sum \frac{(O-E)^{2}}{E} \\
& \text { With (r-1) (c-1) degrees of freedom. }
\end{aligned}
$$

Where,

$$
\begin{aligned}
& O \text { - Observed frequency } \\
& \text { E- Expected frequency } \\
& \text { C - Number of rows in a contingency table } \\
& \mathrm{R} \text { - Number of column in a contingency table }
\end{aligned}
$$

' $t$ ' test has been used to examine the significance in change of prepost credit periods.

In order to access the contribution of independent variables to women empowerment, step wise multiple regression analysis was carried out.

\section{Impact of Micro Credit on Economic Empowerment of Women}

The economic empowerment is measured with the help of increase in assets value, income, Savings, loan amount and family income. The indices of economic indicators of each member are prepared at pre and post-credit stages. The indices are classified as upto 20, 21-40, $41-60,61-80,81-100$. The distribution of pre and post-credit stages is presented in Table 1 .

The above Table 1 shows that in the case of manufacturing sector activity 18.52 per cent of the respondents have an index upto 20 in the pre-credit whereas the figure declines 60 to 75 per cent in the postcredit stage. Followed by this the respondents who have an index value between $21-40$ at pre-credit stage make up 20.99 per cent and the figures declined to 13.58 per cent in the post-credit stage. The percentage of the respondents who have an index value above 81-100 at pre-credit stage is 20.98 per cent and it has increased to 27.16 per cent at the post-credit stage.

In the case of service sector activity 11.76 per cent of the respondents have an index upto 20 in the pre-credit where as the figure declines 60 to 75 per cent in the post-credit stage. The respondents who have an index value between 21-40 at pre-credit stage constitute 28.43 per cent and the figures declined to 12.75 per cent in the post-credit stage. 17.65 percentages of the respondents have an index value above 81-100 at pre-credit stage and the figures have increased to 19.60 per cent at the post-credit stage $[2,3]$.

In the case of trading sector activity 12.82 per cent of the respondents have an index upto 20 in the pre-credit whereas the figure declines to 60 to 75 per cent in the post-credit stage. Followed by this the respondents who have an index value between $21-40$ at pre-credit stage constitute 29.91 per cent and the figures declined to 12.82 per cent in the post-credit stage. The percentages of the respondents who have an index value above $81-100$ at pre-credit stage is 11.97 per cent and the figures has increased to 27.34 per cent at the post-credit stage.

To economic indices of the respondents are compared at pre and post-credit periods. The average economic indices of the respondents in two different sectors at two different periods are calculated. From that the incremental index is drawn. In order to test the significant difference between the two mean values of economic index in each 
Citation: Selvaraj N (2016) Impact of Micro-Credit on Economic Empowerment of Women in Madurai, Tamilnadu: A Study. J Glob Econ 4: 227. doi: $10.4172 / 2375-4389.1000227$

Page 3 of 5

\begin{tabular}{|c|c|c|c|c|c|c|}
\hline \multirow[t]{2}{*}{ Index } & \multicolumn{2}{|c|}{ Manufacturing sector } & \multicolumn{2}{|c|}{ Service sector } & \multicolumn{2}{|c|}{ Trading sector } \\
\hline & Pre-Credit & Post-Credit & Pre-Credit & Post-Credit & Pre-Credit & Post-Credit \\
\hline Upto 20 & $\begin{array}{c}15 \\
{[18.52]}\end{array}$ & $\begin{array}{c}11 \\
{[13.58]}\end{array}$ & $\begin{array}{c}12 \\
{[11.76]}\end{array}$ & $\begin{array}{c}13 \\
{[12.75]}\end{array}$ & $\begin{array}{c}15 \\
{[12.82]}\end{array}$ & $\begin{array}{c}14 \\
{[11.97]}\end{array}$ \\
\hline $21-40$ & $\begin{array}{c}17 \\
{[20.99]}\end{array}$ & $\begin{array}{c}11 \\
{[13.58]}\end{array}$ & $\begin{array}{c}29 \\
{[28.43]}\end{array}$ & $\begin{array}{c}13 \\
{[12.75]}\end{array}$ & $\begin{array}{c}35 \\
{[29.91]}\end{array}$ & $\begin{array}{c}15 \\
{[12.82]}\end{array}$ \\
\hline $41-60$ & $\begin{array}{c}17 \\
{[20.99]}\end{array}$ & $\begin{array}{c}21 \\
{[25.93]}\end{array}$ & $\begin{array}{c}24 \\
{[23.53]}\end{array}$ & $\begin{array}{c}21 \\
{[20.59]}\end{array}$ & $\begin{array}{c}29 \\
{[24.79]}\end{array}$ & $\begin{array}{c}31 \\
{[26.50]}\end{array}$ \\
\hline $61-80$ & $\begin{array}{c}15 \\
{[18.52]}\end{array}$ & $\begin{array}{c}16 \\
{[19.75]}\end{array}$ & $\begin{array}{c}19 \\
{[18.63]}\end{array}$ & $\begin{array}{c}35 \\
{[34.31]}\end{array}$ & $\begin{array}{c}24 \\
{[20.51]}\end{array}$ & $\begin{array}{c}25 \\
{[21.37]}\end{array}$ \\
\hline $81-100$ & $\begin{array}{c}17 \\
{[20.98]}\end{array}$ & $\begin{array}{c}22 \\
{[27.16]}\end{array}$ & $\begin{array}{c}18 \\
{[17.65]}\end{array}$ & $\begin{array}{c}20 \\
{[19.60]}\end{array}$ & $\begin{array}{c}14 \\
{[11.97]}\end{array}$ & $\begin{array}{c}32 \\
{[27.34]}\end{array}$ \\
\hline Total & 81 & 81 & 102 & 102 & 117 & 117 \\
\hline Percentage & 100.0 & 100.0 & 100.0 & 100.0 & 100.0 & 100.0 \\
\hline Average Value of Index & 53.41 & 59.61 & 52.15 & 65.64 & 50.22 & 60.22 \\
\hline
\end{tabular}

Table 1: Distribution of households according to economic index (In Percentage).

\begin{tabular}{|c|c|c|c|c|}
\hline \multirow[b]{2}{*}{ Sector } & \multicolumn{2}{|c|}{ Average Economic Index } & \multirow{2}{*}{$\begin{array}{l}\text { Incremental Index } \\
\text { (2)-(1) }\end{array}$} & \multirow[b]{2}{*}{ t-Statistics } \\
\hline & $\begin{array}{c}\text { Pre-Credit } \\
\text { (1) }\end{array}$ & $\begin{array}{l}\text { Post-Credit } \\
\text { (2) }\end{array}$ & & \\
\hline Manufacturing Sector & 53.41 & 59.61 & 6.20 & $8.1124^{*}$ \\
\hline Service Sector & 52.15 & 65.64 & 13.49 & 5.2516 \\
\hline Trading Sector & 50.22 & 60.22 & 10.03 & $7.6241^{*}$ \\
\hline Overall & 38.63 & 57.41 & 19.25 & $6.2144^{*}$ \\
\hline
\end{tabular}

*Significance at 5 per cent level.

Table 2: Economic index in pre and post credit situation.

\begin{tabular}{|c|c|c|c|}
\hline Economic Variables & \multicolumn{2}{|c|}{ O-Value } \\
\hline & Manufacturing Sector & Service Sector & Trading Sector \\
\hline Assets & $8.7316^{*}$ & $7.6514^{*}$ & $5.1624^{*}$ \\
\hline Income & 6.2661 & $6.0141^{*}$ & 6.1124 \\
\hline Savings & 6.3141 & 5.5141 & 4.6341 \\
\hline Family Income & 7.6215 & $4.3161^{*}$ & 5.2861 \\
\hline Loan Amount & 7.7262 & $6.3516^{*}$ & 6.1621 \\
\hline Overall Economic Index & $7.9162^{*}$ & $6.6929^{*}$ & 6.2761 \\
\hline
\end{tabular}

*Indicates the significant at 5 per cent level.

Table 3: fishers ' $f$ ' test regarding economic variables pre and post credit periods

area and also for overall data, the ' $t$ '- statistics is also computed. The resulting average economic index with its' $t$ ' value for all sectors is shown in Table 2 .

It is learnt from the Table 2 that the average economic indices to the respondents in manufacturing sector, service sector, and trading sector activity had increased by $6.20,13.49$ and 10.03, respectively. For the overall data, the average economic index has increased from 38.63 in pre-credit stage to 57.41 in post-credit. In the case of manufacturing sector activity, the average economic index has increased from 53.41 in pre-credit to 59.61 in post-credit stage. The service sector activity, the average economic index has increased from 52.15 in pre-credit to 65.64 in post-credit stage. Finally, in trading sector activity the average economic index has increased from 50.22 in pre-credit to 60.22 in postcredit stage. The changes of the economic index during the two periods in manufacturing, trading sectors and overall data are statistically significant and change in agricultural and service sectors are not statistically significant [4].

\section{Differences in Economic Variables at Pre and Post Credit Periods}

The ' $t$ ' test is used to find out the significant difference between the two means only. But in the present study, the significant differences in each economic variables at two different periods namely pre and post credit periods are ascertained. The significant differences are measured with the help of Fishers' ' $F$ ' test. The ' $F$ ' values of selected six variables are calculated for the respondents in agriculture, manufacturing, service, trading sectors and overall data. The ' $\mathrm{F}$ ' statistics of assets, income, savings, family income, loan amount and overall economic indices for the different activities.

It has been inferred from the Table 3 that In the case of service sector activity, significant differences exist in economic variables namely the six economic variables in the two different periods of pre and post credit periods.

In the case of trading sector activity, significant differences exist among the respondents regarding all the six economic variables in the two different periods of pre and post credit periods. In the case of overall data, conspicuous variations are noticed in economic variables namely assets, income, savings, family income, loan amount and overall economic index, respectively. It indicates that when the period of membership increases there is a significant change in the economic preferences of the respondents during the pre and post credit periods.

\section{Correlation between Economic Variables and Income Generation}

The relationship between economic variables namely assets 
(material possession), income, savings, family income, loan amount, and overall economic index and the income generations is calculated with the help of Karl Pearson correlation co-efficient at pre and post credit periods [5]. The study of correlation represents how far the variables are correlated with income generation. The correlation coefficient of different economic variables with income generation for two different groups at pre credit periods are calculated separately and shown in Table 4.

It has been observed from Table 4 that all economic variables except the loan amount are positively correlated with the income generation of the respondents in all sectors. The loan amount is negatively correlated with income generations but the correlation co-efficient is insignificant in all sectors.

In manufacturing sector activity, the only significantly correlated variable with the income generation is 'savings'. In service sector activity, only two variables namely savings and family income are positively and significantly correlated and in trading sector activity the only significantly correlated variable with income generation is 'savings'. The overall data shows that there is a significant and positive correlation between the savings and family income of the respondents with income generation at pre credit periods.

The correlation co-efficient between the above said economic variables and income generations at post credit period is also calculated and presented in Table 5 .

Table 5 reveals that all the five economic variables are positively correlated with the income generation of the respondents at post credit periods. The significant variables in all the sectors activity are savings, family income, loan amount and overall economic index. In manufacturing sector activity, the significant variables are savings, loan amount and overall economic index, respectively. In service sector activity, the significant variables are savings, loan amount and overall economic index respectively. In trading sector activity, the significant variables are savings and loan amount respectively. The overall data reveals that the significantly correlated variables are savings, family income, and overall economic index. It is noted that there is a positive correlation between loan amount and income generation in post credit periods because of the purpose of utilization of the loan amount in two different periods of pre-credit and post-credit periods [6]. The higher savings and higher family income are significantly and positively

correlated with income generation. It indicates that the mere loan amount of the respondents is not essential to generate income, while it requires savings and also higher family income.

\section{Summary}

The Economic index was measured and classified as upto 20, 20-40, 41-60, 61-80 and 81-100. The Economic index of the respondents was compared at pre and post-credit stages and to test the significant difference between the two mean value of economic index in each sector, the ' $t$ ' statistic was also computed. The changes of economic index during the pre and post-credit periods in the two sectors in manufacturing sector and trading sector were statistically significant and the changes in other one sectors such a service sector are insignificant.

The ' $F$ ' statistic reveals that in manufacturing sector activity significant difference exists among the respondents regarding all six economic variables in the two different periods. In the case of service sector activity, significant differences exist in economic variables namely the six economic variables in the two different periods of pre and post-credit period situation. In the case of trading sector activity, significant differences exist among the respondents regarding all the six economic variables in the two different periods of pre and post credit period situation. In the case of overall data, compicious variations are noticed in economic variables namely assets, income, savings, family income, loan amount and overall economic index respectively. It indicates that when the period of membership increases there is a significant change in the economic preferences of the respondents during the pre and post credit periods.

\section{Suggestions and Conclusion}

Regarding the enrolment of membership, SHGs consisting of members of Below Poverty Line should enroll only a person of Below Poverty Line. Then only, they can utilize the economic benefits like the revolving fund and subsidies given by banks.

The facilitators like NGOs, banks should communicate information to start self-employment in the field which provides ample opportunities for income generation with the locally available raw materials.

Among all the sectors, agricultural sector lacks behind in earning

\begin{tabular}{|c|c|c|c|}
\hline Economic Variables & \multicolumn{3}{|c|}{ F-Value } \\
\hline & Manufacturing Sector & Service Sector & Trading Sector \\
\hline Assets & 0.4611 & 0.1543 & 0.1732 \\
\hline Savings & $0.5764^{*}$ & $0.6761^{*}$ & $0.4621^{*}$ \\
\hline Family Income & 0.5141 & $0.4738^{*}$ & 0.6761 \\
\hline Loan Amount & -0.2761 & -0.2761 & -0.5315 \\
\hline Overall Economic Index & 0.2761 & 0.2617 & $-0.5861^{*}$ \\
\hline
\end{tabular}

*Indicates the significant at 5 per cent level.

Table 4: Relationship between economic variables and income generation in pre credit.

\begin{tabular}{|c|c|c|c|}
\hline Economic Variables & \multicolumn{2}{|c|}{ F-Value } \\
\hline & Manufacturing Sector & Service Sector & Trading Sector \\
\hline Assets & 0.4361 & 0.3462 & 0.3015 \\
\hline Savings & $0.5241^{*}$ & $0.3361^{*}$ & $0.4364^{*}$ \\
\hline Family Income & 0.0421 & 0.4216 & 0.4264 \\
\hline Loan Amount & $0.5265^{*}$ & $0.2254^{*}$ & $0.5762^{*}$ \\
\hline Overall Economic Index & $0.4262^{*}$ & $0.2914^{*}$ & $0.5264^{*}$ \\
\hline
\end{tabular}

*Indicates the significant at 5 per cent level.

Table 5: Relationship between economic variables and income generation in post credit periods. 
Citation: Selvaraj N (2016) Impact of Micro-Credit on Economic Empowerment of Women in Madurai, Tamilnadu: A Study. J Glob Econ 4: 227. doi: $10.4172 / 2375-4389.1000227$

Page 5 of 5

income. This sector can engage them in contract farming and cultivate profitable crops.

The NGOs can provide some common services to the Self-Help Groups for procurement of raw materials, marketing etc.

\section{References}

1. Kulshrestha LR (2000) Micro-Finance: The New Development Paradigm for Poor Rural Women.
2. Lakshmi Devi KR (2005) Micro Credit Programmes, Poverty Alleviation and Empowerment of Women-Some Empirical Evidence from Kerala.

3. Meenakshi R (2006) Role of Information and Communication Technology (ICTs) in Empowering Women.

4. Meenambigai J (2004) Self-Help groups in Rural Economy. Kisan World.

5. Pandmini S (1974) The Study of Women in India.

6. Tripathy KK (2006) Micro-credit Intervention and Poverty alleviation. 